\title{
MOTIVASI KEWIRAUSAHAAN PETANI PADI ORGANIK DI KABUPATEN BANTUL
}

\author{
Nur Rahmawati ${ }^{1)}$, Triyono $^{2)}$, Sriyadi $^{3)}$ \\ Fakultas Pertanian, Universitas Muhammadiyah Yogyakarta \\ Email : rahma_wati_mf@yahoo.com
}

\begin{abstract}
The improvement of farmers' welfare, especially rice farmers require efforts to improve the ability of farmers to produce quality products and which is competitive. An effort that can be done is to increase the motivation of entrepreneur communities through organic farming which can be expected to ensure the preservation of the environment for sustainable production, achieve food security at the same time improving the welfare of people that having quality.This research aims to identify the motivation of entrepreneur farmers and the individual factors and the influence of environments. The study was conducted by interview survey method on organic rice farmers, then it was analyzed by descriptive and regression analysis. The results showed that the general motivation of entrepreneur farmers is strong enough. Factors that influence entrepreneurmotivation is the business environment; access to credit, market orientation, a network of cooperation and support from the government as well as individual factors, namely education.
\end{abstract}

Keywords : motivation, entrepreneur, organic rice farming

\begin{abstract}
Abstrak : Peningkatan kesejahteraan petani khususnya petani padi memerlukan usaha peningkatan kemampuan petani dalam menghasilkan produk yang berkualitas dan berdaya saing. Salah satu upaya yang dapat dilakukan adalah peningkatan motivasi kewirausahaan masyarakat melalui pertanian organik yang dapat diharapkan mampu menjamin kelestarian lingkungan bagi produksi yang berkelanjutan, mewujudkan ketahanan pangan sekaligus peningkatan kesejahteraan masyarakat yang berkualitas. Penelitian ini bertujuan untuk mengidentifikasi motivasi kewirausahaan petani serta faktor-faktor individu dan lingkungan yang berpengaruh. Penelitian dilakukan dengan metode survei wawancara pada petani padi organik, kemudian dianalisis secara deskriptif dan analisis regresi. Hasil penelitian menunjukkan bahwa Secara umum motivasi kewirausahaan petani sudah cukup kuat. Faktor-faktor yang mempengaruhi motivasi kewirausahaan adalah lingkungan usaha yaitu akses kredit, orientasi pasar, jaringan kerjasama dan dukungan pemerintah serta faktor individu yaitu pendidikan.
\end{abstract}

Kata Kunci : motivation, entrepreneur, organic rice farming

\section{PENDAHULUAN}

Produk organik, termasuk beras organik merupakan pangan yang dihasilkan oleh pertanian organik (Biao, 2003). Pangan organik diyakini lebih aman (Canavari et al 2002) karena merupakan pangan alami yang dihasilkan tanpa menggunakan bahan kimia dan pupuk buatan (Connor dan Douglas, 2002). Produk pangan organik dihasilkan dari pertanian organik, suatu sistem produksi yang mempertahankan kesehatan tanah, ekosistem dan manusia (USDA 2010).

Tren preferensi konsumen terhadap produk organik ditunjukkan oleh permintaan produk organik khususnya beras yang semakin meningkat dari tahun ke tahun.Sejak tahun 2006 produksi beras organik belum mampu memenuhi kebutuhan pasar.Bahkan pada tahun 2009 produksi beras organik hanya mampu 
memenuhi kebutuhan sekitar 50\% dari permintaan pasar.Hal ini disebabkan karena laju permintaan beras organik belum bisa diimbangi oleh laju produksinya.

Tabel 1. Produksi dan Kebutuhan Pasar Beras Organik di Indonesia

\begin{tabular}{ccc}
\hline Tahun & $\begin{array}{c}\text { Produksi } \\
(\mathrm{kg})\end{array}$ & $\begin{array}{c}\text { Kebutuhan Pasar } \\
(\mathrm{kg})\end{array}$ \\
\hline 2005 & 550.300 & 550.300 \\
2006 & 557.179 & 660.360 \\
2007 & 563.865 & 792.432 \\
2008 & 570.519 & 950.918 \\
2009 & 577.080 & 1.141 .102 \\
\hline
\end{tabular}

Sumber : Pertanian Sehat Indonesia.com

Pada Tahun 2009, sebanyak tiga persen dari total 58.000 hektar lahan sawah di Daerah Istimewa Yogyakarta menerapkan sistem organik. Sedangkan di Kabupaten Bantul, dari 16.000 hektar lahan padi, baru lima persen diantaranya tersertifikasi organik (http:// ibutani.blogspot.com). Dengan demikian, berdasarkan luas yang telah diusahakan masih menunjukkan bahwa baru sebagian kecil potensi lahan yang dikembangkan dalam menangkap peluang pasar padi organik yang masih cukup terbuka.

Pemanfaatan potensi sumberdaya alam pertanian, dalam hal ini adalah lahan tergantung pada potensi sumberdaya manusia khususnya petani.Selama ini peran petani sebagai pelaku utama yang memiliki kemampuan kreativitas dan daya cipta kurang dimaksimalkan potensinya. Berdasarkan realitanya keberhasilan petani mencapai kinerja usahatani yangtinggi tidak hanya ditentukan oleh kegiatan teknik budidava sernata tetapi juga ditentukan oleh kemampuan petani baik sikap, pengetahuan dan ketrampilan yang diaktualisasikan dalam menjalankan usahataninva mulai dari persiapan tanam sampai pemasaran produk yang dihasilkan.

Saragih (1996) menyatakan bahwa kewirausahaan petani merupakan salah satu faktor yang sangat penting dalam menentukan keberhasilan usaha yang berorientasi pasar. Demikian pula menurut beberapa pendapat yang lain Hartono, (2003) mengatakan bahwa melalui pengembangan bisnis untuk petani kecil diharapkan mampu menurnbuhkan dan mengembangkan petani-petani inovator dan motivator yang berjiwa entrepreneur.
Kewirausahaan penting untuk pengembangan agribisnis, oleh karena kewirausahaan petani perlu ditumbuhkan menghadapi tekanan lingkungan pasar yang tidak kondusif (Wibowo dan Subiyono, 2005; Priyanto, 2008).

Tujuan penelitian ini adalah mengetahui motivasi kewirausahaan petani pada usahatani padi organik dan mengetahui faktor-faktor yang mempengaruhi motivasi kewirausahaan petani pada usahatani padi organik.

\section{TINJAUAN PUSTAKA}

\section{Motivasi}

Motivasi dipandang sebagai segala sesuatu yang menginspirasi tindakan manusia termasuk didalamnya aspirasi atau niat dalam perilaku (Mansor dan Mat 2010). Motivasi seseorang untuk menjadi entrepreneur cukup beragam.

Dari kebanyakan survey yang dilakukan di negara industri disebutkan bahwa motivasi yang mendorong laki-laki dan perempuan dalam melakukan usaha hampir sama, dimana kebebasan dan kebutuhan untuk pencapaian diri (need of self achievement) selalu berada di urutan teratas (Hisrich et al. 2001).

Orhan dan Scott dalam Kasali et all (2011)menjelaskan ada tujuh motif untuk menjadi seorang pengusaha. Pertama dynastic compliance (turunan) dimana usaha tersebut memiliki sejarah panjang dalam keluarga. Kedua no other choice (tidak ada pilihan). Ketiga entrepreneur by change yaitu mereka yang menjalankan entrepreneur karena menerima bukan mencari peran tersebut. Keempat natural succession yaitu suksesi yang memang telah dipersiapkan dalam menjalankan bisnis keluarga setelah mendapatkan pendidikan. Kelima forced entrepreneur yaitu karena adanya tekanan. Keenam informed entrepreneur yaitu melakukan usaha karena dipengaruhi lingkungan terdekatnya. Ketujuh pureentrepreneur yaitu menjalankan bisnis sendiri secara alami berdasarkan pengalaman.

Motivasi dipengaruhi oleh 2 faktor yaitu faktor pendorong (push factor) dan faktor penarik (pull factor). Faktor pendorong adalah faktor faktor yang berasal dari dalam diri petani. Sedangkan faktor penarik adalah faktor yang berasal dari luar petani (Kasali,2011).

Dari kebanyakan survey yang dilakukan di negara industri disebutkan bahwa motivasi 
yang mendorong laki-laki dan perempuan dalam melakukan usaha hampir sama, dimana kebebasan dan kebutuhan untuk pencapaian diri (need of self achievement) selalu berada di urutan teratas (Hisrich et al. 2001).

\section{Faktor Penentu Motivasi Kewirausahaan}

1. Faktor Individu

a. Pendidikan. Agar usaha dapat bersaing di pasar global, peran pendidikan bagi entreprenenur menjadi semakin penting. Selain dapat membantu meningkatkan kemampuan usahanya, mengidentifikasi pilihan dan membuat keputusan juga dapat menambah informasi yang akan digunakan saat menjalankan usahanya, menentukan kedalaman lokus perencanaan dan memiliki dampak yang signifikan pengembalian aset (Gatheya et.al, 2011).

b. Umur. Ainin et al (2010) melaporkan bahwa umur dan gender entrepreneur signifikan mempengaruhi kinerja bisnis.

c. Umur Usaha dan Pengalaman.Stam et al. dalam Minniti dan Naude (2010) mengatakan bila seseorang memulai suatu usaha baru setelah sebelumnya mengalami kegagalan tergantung pada kapasitasnya belajar dari pengalaman. Inilah yang disebut sebagai habitual entrepreneurship.

2. Lingkungan Usaha

a. Akses Modal dan Kredit. Diantara faktorfaktor lingkungan yang paling penting dalam aktivitas entrepreneur diantaranya adalah bantuan finansial atau aksesibilitas kredit (Mat dan Razak, 2011). Permasalahan ini lebih sering terdengar di negara berkembang terkait dengan pengangguran dan diskriminasi gender (Carter dan Shaw, 2006).

b. Pelatihan. Bagi entrepreneur kesenjangan akses terhadap pelatihan dan konsultasi merupakan alasan utama yang selalu digunakan untuk menjelaskan kinerja mereka yang rendah (Roomi dan Harrison, 2008).Pelatihan lebih dipandang sebagai suatu biaya dan bersifat reaktif dibandingkan sebagai suatu investasi dan bagian dari strategi perencanaan bisnis.

c. Orientasi Pasar. Studi orientasi pasar hanya dilakukan pada pabrik, jasa dan perusahaan ritel besar di Amerika Serikat dan Eropa Barat dan sangat sedikit dilaporkan dalam literatur tentang perilaku pemasaran bisnis di negara sedang berkembang maupun negara belum berkembang, terlebih lagi tentang perilaku pemasaran usaha kecil yang dikelola perempuan (Afza, Hasan dan Rashid, 2010).

d. Skala Usaha. Banyak studi melaporkan bahwa skala usaha merupakan salah satu faktor penting bagi proses organisasi dan kinerja (Baum et al. 2001).

e. Jaringan (network). Kurangnya jaringan merupakan hal yang banyak ditemukan dalam entrepreneurship, (Itani et al. 2009).Miskinnya keragaman dalam jaringan yang dimilikientrepreneur sebagai akibat dari kurangnya hubungan dengan orangorang yang menjadi faktor kunci dan pemasok inti dalam kegiatan mereka selama ini.

Tabel 2. Skor Jawaban Petani Padi Organik terhadap Indikator Motivasi Petani

\begin{tabular}{|c|c|c|c|c|c|c|c|c|c|c|}
\hline \multirow{2}{*}{ Indikator/ skore } & \multicolumn{2}{|c|}{1} & \multicolumn{2}{|c|}{2} & \multicolumn{2}{|r|}{3} & \multicolumn{2}{|c|}{4} & \multicolumn{2}{|r|}{5} \\
\hline & $\mathrm{F}$ & $\%$ & $\mathrm{~F}$ & $\%$ & $\mathrm{~F}$ & $\%$ & $\mathrm{~F}$ & $\%$ & $\mathrm{~F}$ & $\%$ \\
\hline \multicolumn{11}{|l|}{ Faktor Pendorong } \\
\hline Pendapatan Kurang & 1 & 0,86 & 10 & 8,62 & 5 & 4,31 & 82 & 70,69 & 18 & 15,52 \\
\hline Tidak puas dengan pendapatan & 1 & 0,86 & 22 & 18,97 & 3 & 2,59 & 84 & 72,41 & 6 & 5,17 \\
\hline Kesulitan mendapat pekerjaan & 7 & 6,03 & 71 & 61,21 & 8 & 6,90 & 27 & 23,28 & 2 & 1,72 \\
\hline Waktu yang fleksibel & 1 & 0,86 & 23 & 19,83 & 0 & - & 76 & 65,52 & 14 & 12,07 \\
\hline \multicolumn{11}{|l|}{ Faktor Penarik } \\
\hline Kebebasan bisnis padi organik & 0 & - & 0 & - & 4 & 3,45 & 96 & 82,76 & 16 & 13,79 \\
\hline Pemenuhan keinginan diri & 0 & - & 1 & 0,86 & 1 & 0,86 & 99 & 85,34 & 15 & 12,93 \\
\hline Padi Organik menjanjikan & 0 & - & 13 & 11,21 & 25 & 21,55 & 65 & 56,03 & 13 & 11,21 \\
\hline Padi Organik diakui masyarakat & 0 & - & 5 & 4,31 & 31 & 26,72 & 75 & 64,66 & 5 & 4,31 \\
\hline
\end{tabular}




\section{Nur Rahmawati, Triyono, Sriyadi : Motivasi Kewirausahaan Petani Padi Organik...}

f. Dukungan Pemerintah. Tambunan (2005) melaporkan bahwa dalam beberapa kasus kebijakan pengembangan kelompok (cluster development policies) di Indonesia belum berjalan dengan sukses. Hal ini disebabkan masih diabaikannya keterkaitan antara kelompok usaha dengan pasar, semakin berkurangnya potensi UKM dalam mengorganisasi diri sendiri dan terbatasnya dukungan dari pemerintah lokal dan organisasi lainnya.

\section{METODE PENELITIAN}

Penelitian dilakukan dengan metode penelitian survei pada petani padi organik di Kabupaten Bantul sebagai obyek penelitian. Sentra pengembangan padi organik di Kabupaten Bantul meliputi: Kecamatan Bambanglipuro, Kecamatan Pandak, Kecamatan Imogiri, Kecamatan Pundong. Dari 4 kecamatan tersebut ada 6 kelompok tani yang masih aktif dalam usahatani padi organik, masing-masing kelompok tani terpilih diambil sampel petani secaranonproporsional random sampling sebanyak 20 sampel petani tiap kelompok, sehingga ada 120 responden.

Penelitian ini menggunakan analisis deskriptif untuk menggambarkan karakteristik kewirausahaan petani dan. pengaruh faktor individu dan lingkungan usaha terhadap karakteristik kewirausahaan. Kemudian dilakukan analisis regresi.

$Y=\beta_{0}+\beta_{1} X_{1}+\beta_{2} X_{2}+\beta_{3} X_{3}+\cdots+\beta_{9} X_{9}$

$\mathrm{Y}=$ Skor Faktor Pendorong/Faktor Penarik

$\beta_{0}=$ Konstanta

$\beta_{1}-\beta_{9}=$ Koefisien Regresi

$X_{1}=$ Akses mendapatkan kredit (Skor)

$X_{2}=$ Pelatihan (Skor)

$X_{3}=$ Orientasi pemasaran (Skor)

$X_{4}=$ Jaringan kerjasama (Skore)

$X_{5}=$ Dukungan Pemerintah (Skore)

$X_{6}=$ Umur (tahun)

$X_{7}=$ Pendidikan (tahun)

$X_{\mathrm{B}}=$ Tanggungan Keluarga (orang)

$X_{9}=$ Pengalaman (tahun)

\section{HASIL DAN PEMBAHASAN}

Hasil penelitian ini bertujuan untuk mengetahui motivasi kewirausahaan dan faktor-faktor yang mempengaruhi motivasi kewirausahaan petani padi organik di kabupaten Bantul. Penelitian dilakukan pada 116 responden petani padi organik dikabupaten Bantul karena ada 4 responden yang tidak memenuhi syarat sebagai responden.

\section{Motivasi Kewirausahaan}

Motivasi adalah suatu proses untuk membuat banyak motif- motif dari perbuatan atau tingkah laku untuk memenuhi kebutuhan dalam mencapai tujuan. Dengan tujuan yang diinginkan ini tentunya harus dibarengi dengan kesiapan dari dalam diri untuk mendorong tingkah laku untuk berbuat sesuatu mencapai tujuan.Ada 2 faktor dalam mengukur motivasi pada usahatani organik yaitu faktor pendorong dan faktor penarik.

Tabel 2 menunjukkan bahwa sebagian besar petani pada faktor pendorong yaitu lebih dari $65 \%$ menjawab dengan skore 4 kecuali pada indikator petani termotivasi untuk berusahatani padi organik karena kesulitan mendapat pekerjaan. Hal ini disebabkan karena petani merupakan pekerjaan pokok, sehingga usahatani padi organik bukan satu satunya jenis usahatani yang dilakukan petani.

Dilihat dari faktor penarik dalam indikator motivasi petani untuk berusahatani padi organik, lebih dari $80 \%$ petani memberikan jawaban skore 4 yaitu berusahatani padi organik adalah bebas dan 'menjanjikan hanya $56 \%$ yang memberikan jawaban dengan skore 4 dan $21 \%$ yang memberikan jawaban dengan skore 3 . Demikian pula indikator bahwa padi organik diakui masyarakat skore jawaban petani masih berkisar pada skore 3 dan 4 .

\section{Faktor Yang Mempengaruhi Motivasi Kewirausahaan}

Faktor yang mempengaruhi karakter wirausaha terdiri dari faktor individu petani dan faktor lingkungan Bisnis

1. Faktor Individu

Faktor individu yang berpengaruh terhadap kewirausahaan adalah faktor dari dalam diri 
petani padi organik yaitu umur petani, pengalaman berusahatani padi organik dan pendidikan petani. Berdasarkan tabel 3 diketahui bahwa lebih dari $50 \%$ petani berumur lebih dari 47 tahun, komposisi umur yang terbanyak adalah umur antara 47 tahun sampai dengan 60 tahun. Ini merupakan umur produktif petani padi organik.Rata-rata umur petani padi organik adalah 55 tahun.

Pengalaman petani padi organik dalam pengelola usahatani padi antara 8 sampai 10 tahun yaitu sebesar $42 \%$ dengan rata-rata pengalaman petani 15 tahun. Hal ini menunjukkan bahwa dalam mengelola usahatani padi terutama padi organik sudah tidak diragukan lagi .

Komposisi tingkat pendidikan petani padi organik sangat bervariasi antara yang berpendidikan SD, SMP dan SMA. Jumlah petani yang berpendidikan SMA yang paling banyak sedangkan yang berpendidikan PT yang terendah yaitu hanya $2,59 \%$. Kondisi ini menunjukkan bahwa tingkat pendidikan petani sudah sangat baik sehingga memudahkan petani dalam menerima transfer teknologi baru dalam rangka meningkatkan pendapatan petani.

\section{Faktor Lingkungan Bisnis}

Faktor lingkungan bisnis merupakan faktor di luar yang berpengaruh terhadap karakter kewirausahaan. Faktor lingkungan bisnis terdiri dari akses untuk mendapatkan modal, syarat mendapatkan modal, frekuensi pelatihan, Orientasi pemasaran, Network (kerjasama) dan dukungan pemerintah.
Akses untuk mendapatkan modal yang terdiri dari jarak dan waktu tempuh untuk mendapatkan kredit/ modal menunjukan skore 1 dan 2 yang artinya jarak untuk mendapatkan kredit cukup dekat yaitu kurang dari $1 \mathrm{~km}$ dengan waktu tempuh kurang dari 15 menit.

Syarat untuk mendapatkan kredit juga mudah bagi yang mempunyai pinjaman modal yang ditunjukkan dengan skore 4 dengan nilai skore sebesar $34 \%$. Skore 1 menunjukkan bahwa petani tidak memanfaatkan kredit. Sedangkan jawaban kesesuaian kredit yang diambil sebesar $44 \%$ menunjukkan skore 3 .

Frekuensi mengikuti pelatihan bagi petani organik sangat bervariasi antara 1 sampai dengan 10 kali untuk pelatihan tentang pertanian organik secara umum dan 1 sampai 6 kali untuk pelatihan padi organik, membuat pupuk organik dan membuat obat/pestisida organik. Frekuensi rata rata untuk pelatihan pertanian organik sebanyak 4 kali, untuk pelatihan padi organik sebanyak 3 kali, pelatihan pembuatan pupuk organik dan pestisida organik masing- masing 2 kali.

Orientasi pemasaran bagi petani padi organik sudah cukup baik artinya petani sudah berani membuka terobosan baru dalam pemasaran yaitu menjual padi sudah dalam bentuk beras sehingga harganya bisa lebih tinggi dibanding dijual dalam bentuk gabah kering atau basah apalagi ditebas. Seperti ditunjukkan dalam tabel 4, jawaban skore petani yang menjual beras adalah $60 \%$ untuk skore 4 dan $30 \%$ untuk skore 5 .

Tabel 3. Faktor Individu Petani Padi Organik

\begin{tabular}{|c|c|c|c|c|}
\hline No & Komponen & Katagori & Jumlah & Persen $(\%)$ \\
\hline \multirow{5}{*}{1} & \multirow{5}{*}{ Umur(th) } & $19-32$ & 2 & 1,72 \\
\hline & & $33-46$ & 25 & 21,55 \\
\hline & & $47-60$ & 61 & 52,59 \\
\hline & & $61-74$ & 25 & 21,55 \\
\hline & & $>74$ & 3 & 2,59 \\
\hline \multirow{5}{*}{2} & \multirow{5}{*}{ Pengalaman(th) } & $8-10$ & 49 & 42,24 \\
\hline & & $11-19$ & 18 & 15,52 \\
\hline & & $20-28$ & 22 & 18,97 \\
\hline & & $29-37$ & 13 & 11,21 \\
\hline & & $>37$ & 14 & 12,07 \\
\hline \multirow{4}{*}{3} & \multirow{4}{*}{ Pendidikan } & SD & 40 & 34,48 \\
\hline & & SMP & 25 & 21,55 \\
\hline & & SMA & 48 & 41,38 \\
\hline & & PT & 3 & 2,59 \\
\hline
\end{tabular}


Tabel 4. Skor Jawaban Petani Padi Organik terhadap Indikator Lingkungan Bisnis

\begin{tabular}{|c|c|c|c|c|c|c|c|c|c|c|c|}
\hline \multirow{2}{*}{ No } & \multirow{2}{*}{ Indikator / Skore } & \multicolumn{2}{|c|}{1} & \multicolumn{2}{|c|}{2} & \multicolumn{2}{|c|}{3} & \multicolumn{2}{|c|}{4} & \multicolumn{2}{|c|}{5} \\
\hline & & Frek & $\%$ & Frek & $\%$ & Frek & $\%$ & Frek & $\%$ & Frek & $\%$ \\
\hline \multirow[t]{3}{*}{1} & Akses terhadap modal dan kredit & & & & & & & & & & \\
\hline & Jarak mendapatkan kredit & 30 & 25,86 & 66 & 56,90 & 7 & 6,03 & 5 & 4,31 & 7 & 6,03 \\
\hline & Waktu tempuh & 43 & 37,07 & 55 & 47,41 & 6 & 5,17 & 8 & 6,90 & 4 & 3,45 \\
\hline \multirow[t]{3}{*}{2} & Syarat mendapatkan modal & & & & & & & & & & \\
\hline & Tingkat kemudahan & 42 & 36,21 & 2 & 1,72 & 32 & 27,59 & 40 & 34,48 & 1 & 0,86 \\
\hline & Kesesuaian kredit yang diambil & 49 & 42,24 & 5 & 4,31 & 51 & 43,97 & 11 & 9,48 & 0 & - \\
\hline \multirow[t]{5}{*}{3} & Frek mengikuti Pelatihan & & & & & & & & & & \\
\hline & Pelatihan Pertanian Organik & 44 & 37,93 & 33 & 28,45 & 23 & 19,83 & 3 & 2,59 & 13 & 11,21 \\
\hline & Pelatihan Padi Organik & 50 & 43,10 & 33 & 28,45 & 21 & 18,10 & 3 & 2,59 & 9 & 7,76 \\
\hline & Pelatihan membuat pupuk Organik & 21 & 18,10 & 41 & 35,34 & 12 & 10,34 & 37 & 31,90 & 5 & 4,31 \\
\hline & Pelatihan membuat obat Organik & 32 & 27,59 & 43 & 37,07 & 29 & 25,00 & 8 & 6,90 & 4 & 3,45 \\
\hline \multirow[t]{6}{*}{4} & Orientasi Pemasaran & & & & & & & & & & \\
\hline & Ditebas di lahan & 51 & 43,97 & 59 & 50,86 & 3 & 2,59 & 3 & 2,59 & 0 & - \\
\hline & Dijual bentuk gabah basah & 33 & 28,45 & 64 & 55,17 & 3 & 2,59 & 15 & 12,93 & 1 & 0,86 \\
\hline & Dijual bentuk gabah kering & 18 & 15,52 & 54 & 46,55 & 6 & 5,17 & 30 & 25,86 & 7 & 6,03 \\
\hline & Dijual bentuk beras & 14 & 12,07 & 7 & 6,03 & 1 & 0,86 & 64 & 55,17 & 30 & 25,86 \\
\hline & Dijual bentuk benih & 25 & 21,55 & 37 & 31,90 & 15 & 12,93 & 26 & 22,41 & 7 & 6,03 \\
\hline \multirow[t]{7}{*}{5} & Network/Kerja Sama & & & & & & & & & & \\
\hline & Frek ketemu dengan peyedia input & 50 & 43,10 & 17 & 14,66 & 24 & 20,69 & 7 & 6,03 & 18 & 15,52 \\
\hline & Frek ketemu dengan kelompok tani & 67 & 57,76 & 17 & 14,66 & 12 & 10,34 & 4 & 3,45 & 15 & 12,93 \\
\hline & Frek ketemu dengan produsen & 70 & 60,34 & 6 & 5,17 & 12 & 10,34 & 10 & 8,62 & 18 & 15,52 \\
\hline & Ada kedekatan emosional dengan & & & & & & & & & & \\
\hline & kelompok tani & 4 & 3,45 & 4 & 3,45 & 6 & 5,17 & 88 & 75,86 & 13 & 11,21 \\
\hline & $\begin{array}{l}\text { Ada kehangatan dan komitmen } \\
\text { terhadapkelompok tani }\end{array}$ & 6 & 5,17 & 9 & 7,76 & 18 & 15,52 & 71 & 61,21 & 12 & 10,34 \\
\hline \multirow[t]{8}{*}{6} & Dukungan pemerintah & & & & & & & & & & \\
\hline & Adanya bantuan modal & 87 & 75,00 & & - & & - & & - & 29 & 25,00 \\
\hline & Adanya pelatihan per tahun & 100 & 86,21 & 8 & 6,90 & 2 & 1,72 & 2 & 1,72 & 4 & 3,45 \\
\hline & Infrastuktur & & & & & & & & & & \\
\hline & a. Perbaikan jalan & 6 & 5,17 & 6 & 5,17 & 4 & 3,45 & 69 & 59,48 & 31 & 26,72 \\
\hline & b. Irigasi & 3 & 2,59 & 11 & 9,48 & 2 & 1,72 & 61 & 52,59 & 39 & 33,62 \\
\hline & c. Penyediaan Pasar & 11 & 9,48 & 30 & 25,86 & 10 & 8,62 & 28 & 24,14 & 37 & 31,90 \\
\hline & d. Sarana Transportasi & 12 & 10,34 & 28 & 24,14 & 6 & 5,17 & 36 & 31,03 & 34 & 29,31 \\
\hline
\end{tabular}

Sedangkan indikator yang lainhasil panen ditebas, dijual bentuk gabah basah dan gabahkeringseperti jawaban skore yang tinggi ada pada skore 1 dan 2 .

Indikator lingkungan bisnis yang lain adalah Network / kerjasama. Tabel 4 menunjukkan bahwa frekuensi ketemuan antara petani dengan penyedia input, kelompok tani dan produsen sebagian besar atau lebih dari 70 $\%$ pada skore 1 artinya frekuensi ketemunya hanya 1 kali saja, namun secara non formal ada kedekatan emosional, kehangatan dan komitmen yang kuat terhadap kelompok tani yang ditunjukan dengan jawaban skore 4 sebanyak $76 \%$ untuk kedekatan emosional dan $61 \%$ untuk adanya kehangatan dan komitmen dengan kelompok tani.

\section{A. Pengaruh Faktor Individu dan Lingkungan Usaha terhadap Motivasi Kewirausahaan}

Motivasi adalah segala sesuatu yang menginspirasi tindakan manusia termasuk didalamnya aspirasi atau niat dalam perilaku.Motivasi yang diamati ada dua, yaitu faktor pendorong (push factor) dan faktor penarik ( pull factor).

\section{Faktor Pendorong}

Faktor pendorong merupakan faktor yang mendorong petani untuk melakukan usahatani padi secara organik. Parameternya adalah 1. pendapatan kurang, 2. Tidak puas terhadap pendapatan sekarang, 3. kesulitan mendapatkan kerja, 4. waktu kerja yang fleksibel karena adanya tanggung jawab terhadap urusan keluarga. Faktor pendorong motivasi petani padi organik dipengaruhi oleh lingkungan usaha dan kondisi individu petani.

Berdasarkan nilai koefisien determinasi $\left(\mathrm{R}^{2}\right)$ hasil analisis menunjukkan bahwa $50 \%$ variabel yang digunakan dapat menjelaskan skor faktor pendorong dalam motivasi 
sedangkan $50 \%$ yang lain dijelaskan oleh faktor lain di luar model. Nilai $F_{\text {hitung }}$ sebesar 4 dan signifikan pada tingkat kesalahan $1 \%$ artinya bahwa faktor Akses mendapatkan kredit, dukungan pemerintah, pelatihan, pendidikan, orientasi pasar, tanggungan keluarga jaringan kerjasama dan pengalaman secara bersama-sama berpengaruh terhadap faktor pendorong dalam motivasi.

Besarnya elastisitas faktor pendorong karena pengaruh lingkungan usaha dan kondisi individu dapat dilihat dari koefisien estimasi faktor-faktor yang mempengaruhi faktor pendorong motivasi petani padi organik disajikan dalam tabel 5 .

Faktor pendorong motivasi petani padi organik dipengaruhi secara signifikan oleh lingkungan usaha berupa akses terhadap kredit dan jaringan kerjasama, sedangkan faktor individu tidak ada yang berpengaruh secara signifikan. Kedua faktor lingkungan usaha tersebut berpengaruh negatif terhadap faktor pendorong motivasi petani dalam berusahatani padi organik.Hal ini bisa dimaknai bahwa jika akses terhadap kredit sulit dan jaringan kerjasama masih minim maka dorongan petani untuk melakukan usahatani padi organik akan makin kuat, dengan harapan mampu meningkatkan pendapatan dan kepuasan terhadap pendapatan yang telah diperolehnya. Namun demikian petani kurang memahami pentingnya kredit bagi pengembangan usahataninya. Akses terhadap kredit yang ada biasa digunakan untuk kebutuhan non pertanian.Hal ini bisa dipahami karena petani berpikir rasional dalam memanfaatkan kredit untuk usaha yang lebih cepat menghasilkan dibanding pertanian agar bisa melakukan pengembalian angsuran kredit yang diajukan.Apablia kredit digunakan untuk usahatani padi maka petani baru bisa melakukan pengembalian angsuran setelah panen atau paling cepat 3-4 bulan kemudian. Oleh karena itu skema pinjaman modal bagi petani perlu ditinjau lagi dengan berbagaai alternatif sistem pengembalian. Sistem bagi hasil modal usaha juga bisa menjadi salah satu alternatif bagi petani dalam mengakses modal yang ada sehingga tidak terbebani angsuran bulanan, tetapi cukup menyetor bagi hasil kepada lembaga permodalan.

Jaringan kerjasama baik dalam hal penyediaan input produksi maupun pemasaran hasil panen padi selama ini belum memberikan keuntungan yang memadai bagi petani. Petani enggan menjalin kerjasama dalam mendapatkan sarana produksi padi jika belum mendapat kepercayaan dari mitra karena harga sarana produksi yang relatif mahal dan belum tersedianya sarana produksi organik sehingga petani cenderung membuat sendiri sarana produksi organik. Hal inilah yang menyebabkan petani kurang bekerja sama dengan mitra penyedia input produksi padi. Selain itu petani kurang berminat bermitra dengan pedagang beras karena beras organik hasil panennya dihargai sama dengan beras non organik, sehingga beras hasil panen dikonsumsi sendiri atau dijual sendiri ke konsumen

Tabel 52. Koefisien estimasi faktor-faktor yang mempengaruhi faktor pendorong motivasi petani padi organik

\begin{tabular}{lccccc}
\hline Variabel & Koefisien & Probablitas & Variabel & Koefisien & Probablitas \\
\hline (Constant) & $2,979 * * *$ & 0,000 & DuPmt & $-0,013$ & 0,744 \\
AksKrd & $-0,072 * * *$ & 0,004 & Umur & 0,018 & 0,641 \\
Plth & 0,009 & 0,822 & Pddk & 0,037 & 0466 \\
OrPsr & 0,011 & 0,689 & TgKlg & $-0,022$ & 0,443 \\
JrKjsm & $-0,149 * *$ & 0,011 & Pglm & 0,003 & 0,896 \\
\hline
\end{tabular}

$\mathrm{R}^{2}=0,508$

$\mathrm{F}_{\text {hitung }}=4,088^{* * *}$

**)Signifikan pada $\alpha=5 \% ; * * *)$ Signifikan pada $\alpha 1 \%$

Keterangan :

AksKrd= Akses mendapatkan kredit

Plth = Pelatihan

OrPsr = Orientasi Pasar

JrKjsm = Jaringan kerjasama

$\begin{array}{ll}\text { DuPmt } & =\text { Dukungan Pemerintah } \\ \text { Pddk } & =\text { Pendidikan } \\ \text { TgKlg } & =\text { Tanggungan Keluarga } \\ \text { Pglm } & =\text { Pengalaman }\end{array}$ 
yang mau membayar dengan harga yang lebih tinggi dibanding beras non organik. Dengan demikian petani padi organik berharap memperoleh pendapatan yang lebih baik.

\section{Faktor penarik}

Faktor penarik adalah faktor yang menarik petani untuk berusaha yang berasal dari diri sendiri, berhubungan dengan eksistensidiri. Parameternya adalah kebebasan, pemenuhan keinginan diri (self fulfilment), dorongan berusaha (entrepreneurial drive), keinginan lebih makmur, status sosial dan kekuasaan. Faktor penarik motivasi petani padi organik dipengaruhi oleh lingkungan usaha dan kondisi individu petani.

Berdasarkan nilai koefisien determinasi $\left(\mathrm{R}^{2}\right)$ hasil analisis menunjukkan bahwa 53\% variabel yang digunakan dapat menjelaskan faktor penarik dalam motivasi sedangkan $47 \%$ yang lain, dijelaskan oleh faktor lain di luar model. Nilai $F_{\text {hitung }}$ sebesar 4,638 dan signifikan pada tingkat kesalahan $1 \%$ artinya bahwa faktor Akses mendapatkan kredit, dukungan pemerintah, pelatihan, pendidikan, orientasi pasar, tanggungan keluarga jaringan kerjasama dan pengalaman secara bersama-sama berpengaruh terhadap faktor penarik dalam motivasi.

Besarnya elastisitas faktor penarik karena pengaruh lingkungan usaha dan kondisi individu dapat dilihat dari koefisien estimasi faktor-faktor yang mempengaruhi faktor penarik motivasi petani padi organik disajikan dalam tabel 6.

Faktor penarik motivasi petani padi organik dipengaruhi secara signifikan oleh lingkungan usaha yaitu akses terhadap kredit, pelatihan, orientasi pasar dan dukungan pemerintah, sedangkan faktor individu tidak ada yang berpengaruh secara signifikan. Akses terhadap kredit, orientasi pasar dan dukungan pemerintah berpengaruh nyata secara positif terhadap faktor penarik motivasi petani padi organik, sedangkan pelatihan berpengaruh nyata secara negatif terhadap faktor penarik motivasi petani padi organik. Ketersediaan kredit usahatani yangmudah diakses, orientasi pemasaran produk beras organik yang jelas serta dukungan pemerintah dalam bentuk penyediaan sarana prasarana transportasi, komunikasi, irigasi dan pemasaran memberikan daya tarik bagi petani untuk melakukan usahatani padi organik.

Sementara itu pelatihan yang diberikan kepada petani cenderung menurunkan minat petani untuk berusahatani padi organik. Petani menilai pelatihan usahatani padi secara organik cenderung rumit dan memerlukan ketekunan petani dalam mengelola usahataninya. Selain itu sarana produksi padi yang memenuhi kaidah organik belum tersedia di pasar dan harus membuat sendiri. Padahal petani selama ini sudah terbiasa dengan teknik budidaya secara konvensional dengan sarana produksi padi yang mudah didapatkan.

Tabel 6. Koefisien estimasi faktor-faktor yang mempengaruhi faktor penarik motivasi petani padi organik

\begin{tabular}{lccccc}
\hline Variabel & Koefisien & Probabilitas & Variabel & Koefisien & Probabilitas \\
\hline (Constant) & $2,831^{* * *}$ & 0,000 & DuPmt & $0,041^{*}$ & 0,063 \\
AksKrd & $0,043^{* * *}$ & 0,002 & Umur & 0,031 & 0,133 \\
Plth & $-0,062^{* * *}$ & 0,004 & Pddk & $0,052^{*}$ & 0,056 \\
OrPsr & $0,024^{*}$ & 0,099 & TgKlg & 0,020 & 0,203 \\
JrKjsm & $-0,022$ & 0,488 & Pglm & $-0,015$ & 0,220 \\
\hline
\end{tabular}

$\mathrm{R}^{2}=0.532$

$\mathrm{F}_{\text {hitung }}=4,638 * * *$

*)Signifikan pada $\alpha 10 \%$; ***)Signifikan pada $\alpha 1 \%$

Keterangan :

AksKrd = Akses mendapatkan kredit

Plth = Pelatihan

OrPsr = Orientasi Pasar

JrKjsm = Jaringan kerjasama

$\begin{array}{ll}\text { DuPmt } & =\text { Dukungan Pemerintah } \\ \text { Pddk } & =\text { Pendidikan } \\ \text { TgKlg } & =\text { Tanggungan Keluarga } \\ \text { Pglm } & =\text { Pengalaman }\end{array}$ 


\section{KESIMPULAN}

Secara umum motivasi kewirausahaan petani sudah cukup kuat dilihat dari faktor pendorong maupun faktor penarik. Faktor-faktor yang mempengaruhi motivasi kewirausahaan adalah lingkungan usaha yaitu akses kredit, orientasi pasar, pelatihan, jaringan kerjasama dan dukungan pemerintah serta faktor individu yaitu pendidikan.

Dalam rangka penguatan motivasi kewirausahaan petani padi organik maka pengembangan lingkungan usaha sangat diperlukan terutama penyediaan modal dengan skema pengembalian saat panen atau sistem bagi hasil. Selain itu diperlukan dukungan pemerintah berupa pelatihan dan penyediaan sarana dan prasarana transportasi, komunikasi, irigasi dan pasar serta pendampingan yang terarah secara intensif dan berkelanjutan.

Selain motivasi petani, perlu kajian lebih komprehensif tentang kewirausahaan petani bagi penguatan karakteristik kewirausahaan petani padi organik dalam rangka pengembangan agribisnis padi organik.

\section{DAFTAR PUSTAKA}

Afza, T. Osman, Mohd Hassan Bin Mohd and Rashid, M. A. (2010). Enterprising behavior ofenterprise-less rural women entrepreneurs of khyber pukhtan khawa of Pakistan.European journal of social sciences, 18, (1), 109-119

Anonim, 2012. Tren Konsumen Beras Organik. http://pertaniansehat.com/ $\mathrm{read} / 2012 / 05 / 28 /$ tabel-padi-organik.htm. available online 11 April 2013.

Anonim, 2011. Luas Tanam Padi Organik. http://ibutani.blogspot.com. available online Januari April 2010.

Baum, J. Robert, Edwin A. Locke dan Ken G. Smith, 2001.A Multidimenssional Model of Venture Growth. Academic Management Journal.Vol 44 (2), 292303.

Biao, Xie., Wang Xiaorong, Ding Zhuhong dan Yang Yaping. 2003. Critical impact assessment of organic agriculture.

Journal of Agricultural and environmental Ethics Vol. 16, 297-311

Canavari, M., Guido Maria Gazzani, Roberta Spadoni dan Domenico Regazzi. 2002. Food safety and organic fruit demand in Italy: a survey. British Food Journal vol. 104 (3-5) pp. 220-232

Carter, S. and Shaw, E. (2006) Women's Business Ownership: Recent Research and Policy Developments.Sheffield, UK: Small Business Service.

Connor, R. dan Lesley Douglas, 2002. Consumer attitudes to organic foods.Nutrition and Food Science vol. 31 (4/5), 254-258

Gatheya, Jane W. et. al. 2011.Interaction between Women Entrepreneurs' Age and Education on Business Dynamic in Small and Medium Enterprises in Kenya.International Journal of Business and Social Science. Vol 2 (15), 265-272.

Hartono, Slamet. 2003. Pengembangan Bisnis Petani Kecil. dalam Widodo (ed). Peran Agribisnis Usaha Kecil dan Menengah untuk Memperkokoh Ekonomi Nasional. Liberty.

Hisrich et al. 2001.Hisrich, Robert D., Michael P. Peters dan Dean A. Shepherd. 2005. Entrepreneurship. McGraw-Hill. New York.

Itani, Hanifa., Yusuf M. Sidani and Imad Baalbaki. 2011. United Arab Emirates Female Entrepreneurs: Motivations and Frustations. Equality, Diversity and Inclusion: An International Journal,Vol. $30(5)$.

Kasali, Rhenald et.al.2011. Modul Kewirausahaan Untuk Program Strata 1.Hikmah. Jakarta.

Mansor, Norudin dan Azman Che Mat. 2010. The Significance of Psychology and Environment Dimensions for Malaysian Muslim Women Entrepreneurships 
Venturing. International Journal of Human Science. Vol 7 (1), 253-269.

Mat, Isidore Ekpe Norsiah dan Razli Che Razak. 2011. Attributes, Environment Factors and Women Entrepreneurial Activity: A Literature Review. Asian Social Science. Vol. 7 (9), 124 - 130.

Minniti, Maria dan Wim Naude. 2010. What Do We Know About The Patterns and Determinants of Female Entrepreneurship Across Countries. European Journal of Development Research.Vol. 22(3), 277-293.

Priyanto, Sony Heru. 2006. Structural Model of Business Performance : Empirical Study on Tobacco Farmers. Gadjah Mada International Journal of Business, January-April 2006. Vol. No. I

Roomi, Muhammad Azam dan Pegram Harrison. 2008. Training Needs for Women-owned SMEs in England. Education and Training,Vol. 50 (8/9), 687-696.

Tambunan, Tulus, 2005. Usaha Kecil dan Menengah di Indonesia: Beberapa Isu Penting. Salemba Empat. Jakarta.

Wibowo, Rudi. 2005. State of The Art Ilmu Ekonomi Pertanian Indonesia. Jurnal Agro Ekonomi, edisi Khusus Tahun XXXV, Oktober 200 